Emil W. Ptywaczewski

\title{
GŁÓWNE TENDENCJE ROZWOJOWE PRZESTĘPCZOŚCI ZORGANIZOWANEJ W POLSCE
}

\section{Uwagi ogólne}

Trzeba pamiętać o tym, iż przestępczość zorganizowana jest częścią przestępczości w ogóle. Łączy się z tym trudne zadanie określenia linii demarkacyjnej pomiędzy przestępczością tradycjonalną a przestępczością zorganizowaną. W naszych warunkach narzędziem rozgraniczającym obie te kategorie w praktyce organów ścigania jest robocza definicja przestępczości zorganizowanej, wypracowana jeszcze w okresie funkcjonowania Wydziału ds. Zwalczania Przestępczości Zorganizowanej Komendy Głównej Policji1 ${ }^{1}$.

Z publikowanych w ostatnich latach statystyk przestępczości wynika, iż utrzymuje się jej tendencja spadkowa, potwierdzana także wynikami badań wiktymizacyjnych, które od lat prowadzone są w Instytucie Wymiaru Sprawiedliwości w Warszawie ${ }^{2}$. Czy możemy zatem mówić także o tendencji spadkowej także w odniesieniu do przestępczości zorganizowanej?

Postawienie takiej tezy byłoby wielce ryzykowne i to z kilku względów. Po pierwsze, interesująca nas kategoria przestępczości rządzi się własnymi prawami, które w konsekwencji utrudniają jej rozpoznanie ${ }^{3}$. Specjaliści wręcz twierdzą, iż dostrzegalna (rozpoznawalna) przestępczość zorganizowana jest źle zorganizowaną przestępczością. Opinia publiczna na ogół jest epatowana w tym zakresie różnymi mitami, które na ogół niewiele mają wspólnego z rzeczywistością, umiejętnie pod-

1 Zob. E.W. Pływaczewski, Organised Crime, (w:) Institute of Justice, Crime and Law Enforcement in Poland on the threshold of the 21st century (edited by Andrzej Siemaszko), Oficyna Naukowa, Warszawa 2000, s. 99; E.W. Pływaczewski, M. Kędzierski, Wybrane aspekty współczesnego terroryzmu i przestępczości zorganizowanej, (w:) Jednostka i społeczeństwo wobec zagrożeń terroryzmem, Biuro Informacji Rady Europy 2002,Biuletyn nr 1, Bliżej. 25-26.

2 Bliżej na ten temat - zob. A. Siemaszko, B. Gruszczyńska, M. Marczewski, Atlas przestępczości w Polsce 4 (pod redakcja naukowa A. Siemaszko), Oficyna Naukowa, Warszawa 2009.

3 Zob. B. Hołyst, „Ciemna liczba” przestępczości zorganizowanej, (w:) Przestępczość zorganizowana w Niemczech Niemczech w Polsce i jej implikacje społeczno-ekonomiczne (praca zbiorowa pod redakcją Brunona Hołysta, Erwina Kube i Rainera Schulte), Warszwa-Muenster-Łódź 1998, s.169 i nast. 
sycanym w mass mediach. Tworzy to różne stereotypy, a niektóre z nich mają już za sobą długą historię 4 .

Niewątpliwie do głębszego rozpoznania samego zjawiska przestępczości zorganizowanej wiele wniosła instytucja świadka koronnego ${ }^{5}$. Skruszeni przestępcy zarówno w USA, Włoszech, jak również w Polsce, dostarczyli organom ścigania niedostępnej dotąd wiedzy, która mogła w istotnym zakresie posłużyć do obnażenia mechanizmów funkcjonowania tego procederu, a przede wszystkim do pociągnięcia do odpowiedzialności karnej jego uczestników i popleczników ${ }^{6}$. Mając na względzie fakt, że ta kategoria przestępczości, w postaci już rozpoznanej, to zaledwie około $1 \%$ ogółu przestępstw, a straty nią powodowane mogą sięgać nawet kilkudziesięciu procent ogółu strat powodowanych przestępczością, należy uznać, iż warto było ponieść wszelkie koszty zarówno w wymiarze materialnym, jak i niematerialnym, jakie pociąga za sobą instytucja świadka koronnego.

Po drugie, rozpoznanie przestępczości zorganizowanej i w rezultacie zaprezentowanie jej w formie statystycznej utrudniają także mało czasem precyzyjne definicje robocze tego procederu, pozwalające na różnego rodzaju manipulacje statystyczne. Można w tym przypadku mówić o zjawisku tzw. rozwodnienia zakresu pojęciowego przestępczości zorganizowanej, prowadzącego rzecz jasna do jej „statystycznego" wzrostu, który niekoniecznie znajdować musi swoje odbicie w rzeczywistości. Przykładowo - prezentowane na 60. Konferencji Amerykańskiego Stowarzyszenia Kryminologii w St. Louis (Missouri) wyniki międzynarodowych badań kryminologicznych wykazały nikły udział przestępczości zorganizowanej w międzynarodowym procederze handlu ludźmi, obalając tym samym mit o wszechobecności tej przestępczości w tej sferze ${ }^{7}$. Znane są także, nie tylko zresztą u nas, próby

$4 \quad$ Przykładem jednego z nich może być historia rzekomego skutecznego skazania Al Capone za przestępstwa i wykroczenia skarbowe. Owa „skuteczność” staje się wielce wątpliwa w świetle wyników zorganizowanej w roku 1990 w Stanach Zjednoczonych eksperymentalnej „powtórki” procesu tego gangstera, w którym przywołano identyczne dowody, dając przy tym swobodę działania - w granicach stanu prawnego z lat trzydziestych - obrońcom oraz ławie oskarżonych. Okazało się, że dla sędziego zabrakło w tym procesie pola do popisu, ponieważ komplet przysięgłych głosował za uniewinnieniem. Skazanie Al Capone na karę jedenastu lat pozbawienia wolności było więc efektem nieudolności najpierw jego doradców podatkowych, później zaś obrońców, zarówno w pierwszej, jak i w drugiej instancji. Szerzej na ten temat - zob. E. Sawicka, Niezwykłe procesy, Bydgoszcz 1998, s. 193 i nast.

5 Szerzej na ten temat - zob. E.W. Pływaczewski, Das polnische Kronzegegesetz in Theorie und Praxis, (w:) Vergleichende Strafrechtswissenschaft. Frankfurter Festschrift für Andrzej J. Szwarc zum 70. Geburtstag, Herausgegeben von Jan C. Joerden, Uwe Scheffler, Arndt Sinn und Gerhard Wolf, Berlin 2009, s. 685 i nast.

$6 \quad$ Szerzej zob. Z. Rau, Instytucja świadka koronnego w świetle wyników przeprowadzonych badań, (w:) Przestępczość zorganizowana. Świadek koronny. Terroryzm - w ujęciu praktycznym, red. E.W. Pływaczewski, Kraków 2005, s. 586 i nast.; L. Kardaszyński, Świadek koronny - 10 lat tradycji, (w:) Praktyczne elementy zwalczania przestępczości zorganizowanej i terroryzmu. Nowoczesne technologie i praca operacyjna, red. Lech Paprzycki, Zbigniew Rau, Warszawa 2009, s. 459 i nast. Zob także relację na temat ostatnich wyników badań świadków koronnych w artykułach Grażyny Zawadki; Świadkowie koronni: jak kupić ludzi władzy oraz Polskie gangi oczami koronnych, jak również Jej rozmowę ze Zbigniewem Rau, Mieszkań czy willi z basenem policja skruszonym przestępcom nie kupuje, Rzeczpospolita z 5 sierpnia 2009, nr 182, s. 1 oraz A4 i A5.

7 Wyniki tych badań sygnalizował James Finckenauer (Rutgers University) w sesji zatytułowanej „Human Frafficking, Organized Crime and Prostitution" w dniu 12 listopada 2008 r. Por. też United Nations - Office on Drugs and Crime, Trafficking in Persons. Global Patterns, Vienna 2006, s. 80-81. 
nacisku różnej maści polityków, aby sprawami z zakresu tradycjonalnej przestępczości, dotyczącymi kręgu ich bliskich bądź znajomych, zajęły się struktury zwalczające przestępczość zorganizowaną, co - w ich mniemaniu - miałoby stanowić większą gwarancję wykrycia i zatrzymania sprawców.

\section{Przestępczość zorganizowana w ujęciu statystycznym}

\section{Dane ogólne}

Od kwietnia 2000 r. w ramach struktur Komendy Głównej Policji funkcjonuje Centralne Biuro Śledcze (CBŚ), kontynuując tradycje i działania powołanego już w 1994 r. Biura do Walki z Przestępczością Zorganizowaną oraz powstałego w 1997 r. Biura do Walki z Przestępczością Narkotykową. CBŚ jest scentralizowaną służbą policyjną specjalizującą się w zwalczaniu zorganizowanej przestępczości, działającą na terenie całego kraju w ścisłym współdziałaniu z innymi służbami Policji. Zgromadzone w poprzednich latach doświadczenia w zakresie walki z przestępczością zorganizowaną wskazywały bowiem jednoznacznie na potrzebę reorganizacji wyspecjalizowanego pionu zwalczającego ten rodzaj przestępczości ${ }^{8}$. W grupie podmiotów tworzących szeroko rozumiany aparat ścigania CBŚ jest służbą szczególnie predestynowaną do zwalczania przestępczości zorganizowanej.

W roku 2001 wzmocniono dotychczasowe struktury CBŚ odpowiedzialne za prowadzenie operacji pod przykryciem oraz realizację zadań wynikających z wdrożenia programów ochrony świadków koronnych i członków ich rodzin. Ponadto w poszczególnych latach CBŚ koordynowało przedsięwzięcia związane z rozpoznaniem i zwalczaniem w skali kraju zagrożeń związanych z przestępczością korupcyjną. W związku z wydarzeniami z dnia 11 września 2001 roku koordynowało też rozpoznanie wszelkich zagrożeń o charakterze terrorystycznym. W CBŚ usytuowano również ogólnokrajowy zespół do walki z fałszerstwami pieniędzy, którego zadaniem jest koordynowanie całości zagadnień związanych z zapobieganiem, rozpoznaniem oraz ujawnianiem i likwidacją nielegalnej produkcji i dystrybucji fałszywych pieniędzy, w tym waluty euro9 ${ }^{9}$ W ramach działalności Biura realizowane są także zadania związane z rozpoznaniem zagrożeń generowanych przez mniejszości etniczne, w tym pochodzące z krajów „,wysokiego ryzyka”.

Ponadto Centralne Biuro Śledcze systematycznie realizuje zadania wynikające z ogólnokrajowych strategii zawartych w takich dokumentach, jak Rządowy pro-

8 Zob. K. Laskowska, Działalność służby Policji do walki z przestępczością zorganizowaną. Detereminanty poprawy skuteczności, Przegląd Policyjny 1999, nr 4, s. 34 i nast.

9 Zob w tej kwestii J. Walaszczyk, Międzynarodowa konferencja poświęcona ochronie euro przed fałszowaniem, Człowiek i Dokumenty 2007, nr 7, s. 29 i nast.; P. Kuzior, Fałszowanie euro jako przejaw działalności zorganizowanych grup przestępczych, Prokurator 2006, nr 4, s. 60 i nast. 
gram poprawy bezpieczeństwa obywateli „Bezpieczna Polska”, Rządowy program przeciwdziałania przestępczości „Razem Bezpieczniej”, „Strategia Antykorupcyjna”, Krajowy Program Zwalczania i Zapobiegania Handlu Ludźmi oraz Narodowy Program Przeciwdziałania Narkomanii.

CBŚ rokrocznie publikuje sprawozdania ze swojej działalności, zawierające m.in. dane statystyczne, a wybrane fragmenty tych sprawozdań od kilku już lat są publikowane na witrynie internetowej tego Biura ${ }^{10}$. Przybliżmy zatem ogólne dane obrazujące efekty działalności tej służby w roku 2008.

Od 1 stycznia do 31 grudnia 2008 roku Zarządy i Wydziały CBŚ w ramach prowadzonych spraw operacyjnych objęły zainteresowaniem 4858 osoby działające w 425 grupach przestępczych, w tym: w 385 grupach polskich, w 32 międzynarodowych, 5 grupach rosyjskojęzycznych oraz w 3 grupach cudzoziemców.

Polskie grupy przestępcze kierowane były przez 342 zidentyfikowanych liderów, grupy międzynarodowe przez 33, rosyjskojęzyczne - 5, cudzoziemców - 2 . Łączna liczba liderów pozostających w zainteresowaniu CBŚ - według stanu na 31 grudnia 2008 roku - wynosiła 382 osoby.

W omawianym okresie sprawozdawczym w zainteresowaniu CBŚ pozostawało 131 grup przestępczych działających w obszarze przestępstw ekonomicznych oraz 147 grup zajmujących się przestępczością narkotykową. Aktywność stricte kryminalną prowadziły 103 zorganizowane grupy, a działalność multiprzestępczą wykazywały 44 takie grupy.

W wyniku krajowych i międzynarodowych działań w zakresie zwalczania zorganizowanej przestępczości CBŚ rozbiło i zdestabilizowało działania łącznie 159 grup przestępczych, w tym 150 polskich i 9 międzynarodowych. Centralne Biuro Śledcze w istotny sposób ograniczyło też aktywność 152 liderów, w tym: 145 liderów grup polskich, 7 liderów grup międzynarodowych oraz 1575 członków grup, z czego 1487 członków grup polskich oraz 88 członków grup międzynarodowych.

Należy podkreślić, iż w 2008 roku CBŚ położyło duży nacisk na rozpoznanie liderów i członków zorganizowanych grup przestępczych oraz ustalanie i zabezpieczanie ich majątku pochodzącego z przestępstwa. Analiza tego zjawiska spowodowała wzrost liczby rozpoznanych grup przestępczych oraz ich liderów i członków. Świadczy to o tym, że wcześniej skazani szefowie grup przestępczych po odbyciu kar wracają na wolność i odbudowują swoje grupy przestępcze. W okresie sprawozdawczym funkcjonariusze CBŚ przedstawili zarzuty 78 cudzoziemcom. Dominującą grupę stanowili obywatele: Ukrainy, Wietnamu, Holandii, Bułgarii i Litwy ${ }^{11}$.

\footnotetext{
10 W niniejszym artykule wykorzystano wybrane fragmenty „Sprawozdania z działalności Centralnego Biura Śledczego KGP”, Warszawa 2009 (opracowanie niepublikowane).

11 Por. K. Laskowska, Działalność cudzoziemskich zorganizowanych grup przestępczych w Polsce w latach 20002006, Białostockie Studia Prawnicze 2007, z. 2, s.175 i nast.
} 
Główne tendencje rozwojowe przestępczości zorganizowanej w Polsce

\section{Wyniki postępowań przygotowawczych prowadzonych przez Centralne Biuro Śledcze}

W 2008 roku Centralne Biuro Śledcze prowadziło łącznie 1931 postępowań przygotowawczych w związku z działalnością zorganizowanych grup przestępczych w różnych kategoriach przestępstw. Statystycznie wszczęto 1064 sprawy, $\mathrm{w}$ tym m.in. podjęto z zawieszenia 64 sprawy, 68 zaś przejęto z innych jednostek. W 178 wypadkach podstawą wszczęcia były własne materiały operacyjne. Zakonczono 1106 spraw, w tym 54 przekazano do innych jednostek, a zawieszono 114. Łącznie w okresie sprawozdawczym zatrzymano 3198 osób, 4817 zaś podejrzanym przedstawiono łącznie 15862 zarzutów.

Wspomniane wyżej postępowania dotyczyły trzech następujących kategorii spraw:

- o charakterze kryminalnym - 539 spraw (w tym 40 o zabójstwa, 24 o zorganizowaną kradzież pojazdów, 18 o fałszerstwa środków płatniczych, 90 o rozboje lub wymuszenia rozbójnicze, 9 o handel ludźmi, 35 o handel bronią, amunicją i materiałami wybuchowymi oraz 322 sprawy o inne przestępstwa kryminalne);

- o charakterze ekonomicznym - 700 spraw (w tym 40 prowadzonych było o przestępstwa przeciwko obrotowi gospodarczemu, 90 z kodeksu karnego skarbowego, 123 o pranie pieniędzy, 93 o korupcję oraz 354 sprawy o inne przestępstwa ekonomiczne);

- o charakterze narkotykowym - 547 spraw, m.in. o przemyt, dystrybucję, produkcję narkotyków oraz 145 spraw o inne przestępstwa narkotykowe

$\mathrm{W}$ odniesieniu do pierwszej z wymienionych kategorii spraw należy podkreślić, iż główne zdarzenia stwarzające zagrożenie dla życia ludzkiego dotyczyły przede wszystkim planowanych zamachów na życie tzw. skruszonych gangsterów, członków ich rodzin oraz funkcjonariuszy odpowiedzialnych za ściganie i zwalczanie przestępczości zorganizowanej. Nową formą tego zjawiska jest pojawienie się tzw. list osób, które mają zostać pozbawione życia w następstwie wydania zlecenia zabójstwa. Istotą tego mechanizmu jest fakt, że informacja ta ma dotrzeć do potencjalnych ofiar. Aby te groźby były realne, sprawcy rzeczywiście posuwają się do zabójstw na zlecenie, o czym z reguły jest głośno w środowiskach przestępczych. Ten schemat postępowania dodatkowo wpływa na obciążenie Policji koniecznością ochrony osób zagrożonych, gdyż groźby te są z reguły realne i uzasadnione. W dalszym ciągu funkcjonuje taktyka skrytego pozbywania się wrogów i potencjalnej konkurencji.

W tzw. sferze ekonomicznej w toku prowadzonych czynności analitycznych wyodrębniono obszary prowadzonej działalności gospodarczej szczególnie nara- 
żone na występowanie zjawiska prania pieniędzy, których specyfika procedur czy pragmatyka działania sprzyja tym patologiom:

- wykorzystywanie instytucji finansowych (banków, domów maklerskich, towarzystw funduszy inwestycyjnych) do legalizowania środków finansowych pochodzących z przestępstw, mieszania środków pieniężnych pochodzących z legalnej działalności ze środkami finansowymi pochodzącymi z działalności przestępczej,

- wykorzystywanie pozafinansowych instytucji do gromadzenia i przechowywania środków finansowych pochodzących z przestępstw w znacznych kwotach,

- wykorzystywanie struktur zorganizowanej przestępczości związanej z przemytem wyrobów tytoniowych i spirytusowych bez polskich znaków skarbowych akcyzy, która generuje znaczne dochody dla członków tych grup,

- wykorzystywanie rynku paliw płynnych, gazowych, obrotu złomem i metalami kolorowymi. Patologiczne zjawiska w obrocie podatkowym na szkodę Skarbu Państwa generują znaczne dochody dla grup przestępczych, jednocześnie powodując znaczne straty dla budżetu Skarbu Państwa. Przestępcza działalność koncentruje się przede wszystkim na uchylaniu się od obowiązków podatkowych, wyłudzaniu nienależnego zwrotu podatku VAT,

- wykorzystywanie rynku kapitałowego, ubezpieczeń i funduszy inwestycyjnych. Legalizowanie środków finansowych z wykorzystaniem mechanizmów inwestycyjnych w 2008 roku ze względu na kryzys na rynkach finansowych nie było atrakcyjne w kategoriach lokaty kapitału. Jednocześnie mechanizmy te były wykorzystywane przez grupy przestępcze przede wszystkim na GPW SA oraz w zakresie nabywania jednostek uczestnictwa funduszy inwestycyjnych,

- wykorzystywanie rynku nieruchomości. W związku z kryzysem na rynku nieruchomości nastąpiła stagnacja na rynku obrotu nieruchomościami. Jednocześnie obserwuje się stały trend związany z inwestowaniem w nieruchomości środków finansowych pochodzących z przestępstw przez zorganizowane grupy przestępcze. Rynek ten jest szczególnie atrakcyjny z uwagi na małe ryzyko inwestycyjne oraz dużą płynność i łatwość dalszego obrotu tymi wartościami,

Środki finansowe pochodzące $\mathrm{z}$ przestępstw dokonywanych przez zorganizowane grupy przestępcze są wykorzystywane m.in. do bieżącego finansowania działalności grupy przestępczej, mieszania środków finansowych pochodzących z przestępstw karnoskarbowych z legalną działalnością biznesową, prowadzenia działalności inwestycyjnej w instrumenty finansowe, w złoto, dzieła sztuki, nieruchomości, korumpowanie funkcjonariuszy publicznych, przedstawicieli biznesu i finansów w celu skuteczniejszego negocjowania warunków kontraktów i umów, 
nabywanie dóbr konsumpcyjnych (nieruchomości, pojazdy). Przykładem w tym zakresie może być śledztwo dotyczące niegospodarnych transakcji w obrocie instrumentami finansowymi polegające na podpisywaniu niekorzystnych finansowo umów nabycia akcji w znacznych kwotach.

Realizując powyższe transakcje, grupa osób naraziła na straty podmioty gospodarcze w kwocie ponad 20.000.000 zł. Uzyskane w ten sposób środki finansowe transferowano z użyciem rachunków bankowych, przy czym istnieje przypuszczenie przeprowadzenia transakcji mających utrudnić lub znacznie uniemożliwić przestępcze pochodzenie tych środków finansowych. W powyższej sprawie w 2008 roku zatrzymano łącznie 7 osób, przedstawiono ogółem 14 zarzutów, w tym 5 z art. 299 kk. dotyczącego prania pieniędzy oraz 9 z art. 296 kk. dotyczącego stypizowanych tam przestępstw nadużycia zaufania i niegospodarności. Zastosowano środki zapobiegawcze, 7 poręczeń majątkowych na ogólną kwotę - 8,6 mln zł. Łącznie zabezpieczono mienie wartości $3 \mathrm{mln}$ zł.

Niektóre postępowania przygotowawcze dotyczą działalności tego rodzaju zorganizowanych grup przestępczych, które nie ograniczają sfery swych działań do jednej tylko z wymienionych wyżej kategorii, co ilustrować może poniższy przykład:

W dniach 27-29.04.2008 r. na terenie Warszawy, Łomianek i Pultuska przeprowadzono realizację, która dotyczyła funkcjonowania zorganizowanej grupy przestępczej zwanej „, mokotowską”. W wyniku działań CBŚ zatrzymano 20 członków grupy zajmujących wysoką pozycję w jej hierarchii, co było bardzo ważne z uwagi na fakt, że zapobiegło dokonaniu planowanych przez przestępców zamachów na życie innych osób, w tym funkcjonariuszy organów ścigania i wymiaru sprawiedliwości. Udział w zorganizowanej grupie przestępczej, rozboje, wymuszenia rozbójnicze, posiadanie broni palnej, a także obrót znacznymi ilościami środków odurzających i czerpanie korzyści z cudzego nierządu to zarzuty, które usłyszeli członkowie grupy „mokotowskiej”. W pierwszej fazie postępowania w sprawie występowało 30 podejrzanych, którym przedstawiono 93 zarzuty, w tym 19 z art. 258 kk. Zastosowano łącznie 28 aresztów, 1 dozór policyjny, zabezpieczenia majątkowe na kwotę 94461 złotych. Sprawa posiada charakter rozwojowy i przewidywane są dalsze zatrzymania członków grupy. Warto też dodać, że w efekcie innych czynności związanych ze sprawą zatrzymano liderów grupy „mokotowskiej”, w tym poszukiwanych z tzw. „top listy” Wojciecha S. ps. „Wojtas”, Artura N. ps. „Należyty” oraz jednego z najbardziej niebezpiecznych przestępców - Marka Cz. ps. „Rympałek”.

Należy podkreślić, że w 2008 roku funkcjonariusze CBŚ współpracowali z policjantami z innych jednostek Policji (KWP, KSP, KMP, KPP) w ramach 72 grup operacyjno-śledczych, które zostały powołane decyzją Komendanta Głównego Policji. 
W zakresie środków zapobiegawczych wobec 1824 osób podejrzanych zastosowane zostały areszty tymczasowe: dozory policyjne objęły 1517 osób, w stosunku zaś do 1330 sprawców zastosowano poręczenia majątkowe. Za 148 podejrzanymi rozesłane zostały listy gończe.

Mimo że w 2008 roku odnotowano nieznaczny spadek efektów pracy dochodzeniowej w postaci zmniejszenia liczy podejrzanych, jak i zatrzymanych oraz stosowanych środków zapobiegawczych, nadal zauważalna jest tendencja wzrostowa osiąganych wyników procesowych w porównaniu do lat poprzednich. Odnotowano również wzrost liczby prowadzonych rozpoznań i rozpracowań operacyjnych. Można prognozować, że utrzymanie dalszego trendu wzrostowego pracy operacyjnej i procesowej może skutkować utrzymaniem wyników na poziomie podobnym do lat poprzednich, a nawet ich wzrostem.

W okresie sprawozdawczym 1575 osobom przedstawiono 1614 zarzuty o czyn $\mathrm{z}$ art. 258 § 1 i $2 \mathrm{kk}$. (tj. udział w zorganizowanej grupie przestępczej). Przepisy tego artykułu zastosowano w stosunku do 1484 członków grup polskich oraz 91 członków grup międzynarodowych. $\mathrm{Z}$ art. $258 \S 3 \mathrm{kk}$. (kierowanie grupą lub związkiem mającym na celu popełnianie przestępstw) przedstawiono natomiast 154 zarzuty 152 osobom. Przepis art. $258 \S 3$ kk. zastosowano w stosunku do 145 liderów grup polskich oraz 7 liderów międzynarodowych grup przestępczych.

Kierownictwo CBŚ kładzie nacisk zarówno na zabezpieczenie mienia, jak również na odzyskiwanie mienia pochodzącego z przestępstw. W prowadzonych sprawach w 2008 roku zabezpieczono mienie w wysokości 169883753 zł. We wszczętych i prowadzonych postępowaniach przygotowawczych odzyskano mienie w wysokości 26055211 zł. Warto w tym miejscu podkreślić, iż w Polsce funkcję krajowego biura ds. odzyskiwania mienia (BOM) pełni 10-osobowy wydział w Biurze Kryminalnym Komendy Głównej Policji ${ }^{12}$.

Centralne Biuro Śledcze zlikwidowało w 2008 roku 15 laboratoriów narkotyków syntetycznych, co świadczy o dobrym rozpoznaniu i przygotowaniu funkcjonariuszy do walki z przestępczością narkotykową, którzy zabezpieczają coraz większą ilość narkotyków pochodzących bezpośrednio z nielegalnych laboratoriów ${ }^{13}$. W sumie w okresie sprawozdawczym CBŚ zabezpieczyło ponad $730 \mathrm{~kg}$ narkotyków ${ }^{14}$. Warto w tym miejscu podkreślić, iż narkotyki syntetyczne zdobywają w Polsce coraz większą popularność. Dostrzegają to zorganizowane grupy przestępcze, które

12 Zob. I. Fedorowicz, Policja tworzy biuro, Policja 997 2009, nr 1, s. 42. Polska już wcześniej dysponowała programem komputerowym, który umożliwi dokładne i wszechstronne poszukiwanie zasobów przestępców. Elektroniczny System Odzyskiwania Mienia będzie programem międzyresortowym, na bieżąco aktualizowanym przez fachowców z Wyższej Szkoły Policji w Szczytnie.

13 Centralne Biuro Śledcze średnio likwiduje ok. 10-15 takich laboratoriów rocznie.

$14 \quad \mathrm{Na}$ uwagę zasługuje również wspólna realizacja prowadzona z Policją niemiecka, w trakcie której na podstawie informacji przekazanej przez funkcjonariuszy CBŚ udaremniono przemyt do Polski 4 ton haszyszu. 
próbują sprostać rosnącemu na nie zapotrzebowaniu. Stąd wzrost przemytu narkotyków i prekursorów do ich produkcji oraz zwiększanie nielegalnej produkcji poprzez organizację coraz większej liczby nielegalnych laboratoriów. Zjawisko to można zauważyć na terenie naszego kraju, który jest jednym $\mathrm{z}$ bardziej zagrożonych nielegalną produkcją amfetaminy. W ostatnich latach zlikwidowano znaczną ilość nielegalnych laboratoriów produkujących ten narkotyk. Są one najczęściej usytuowane w trudno dostępnych i zakamuflowanych miejscach, często wykorzystując sprzęt domowej produkcji (tzw. ,kitchen labs”). Najpopularniejszą metodą produkcji jest metoda Leuckarfa. Przykładem skutecznych działań wykrywczych CBŚ może być następująca sprawa:

CBŚ, prowadząc działania wobec zorganizowanej grupy przestępczej działającej na terenie województwa mazowieckiego, zajmującej się produkcją i handlem narkotykami na dużą skalę, w maju 2008 roku w okolicach Grodziska Mazowieckiego ujawniło duży magazyn narkotykowy, w którym zabezpieczono $62 \mathrm{~kg}$ amfetaminy. Narkotyki zapakowane byty w specjalne torby i przygotowane do odbioru. W zaadaptowanym na magazyn pomieszczeniu gospodarczym zabezpieczono ponadto wagi, stoły oraz pojemniki do porcjowania narkotyku. Gromadzona tu amfetamina trafiała na nielegalny rynek narkotykowy w kraju. W skład grupy wchodziło czterech mieszkańców Grodziska Mazowieckiego. W wyniku przeszukań miejsc zamieszkania zatrzymanych osób zabezpieczono również kanistry z różnego rodzaju odczynnikami służącymi do produkcji amfetaminy. Wobec zatrzymanych zastosowano środki zapobiegawcze w postaci tymczasowego aresztowania.

W ramach zwalczania zorganizowanej przestępczości ekonomicznej funkcjonariusze CBŚ zlikwidowali w okresie sprawozdawczym 2 nielegalne fabryki papierosów. Realizacja zagadnień z tego zakresu wynika $\mathrm{z}$ właściwego monitorowania tego zjawiska, jak również utrzymujących się trendów i opłacalności tego procederu. Oto jeden z przykładów obrazujących skalę tego procederu:

W listopadzie 2008 roku w miejscowości Linin ujawniono nielegalną fabrykę papierosów umiejscowioną w dużej przemysłowej hali. Ujawniono kompletną linię technologiczną mogącą produkować około 20-25 mln sztuk papierosów miesięcznie, co przynosiło straty dla Skarbu Państwa z tytułu niezapłaconych podatków akcyzowego i VAT około 5-6 mln złotych miesięcznie. Papierosy (podróbki znanych marek Marlboro i L\&M) produkowane były przez 6 dni w tygodniu po kilkanaście godzin z przeznaczeniem na rynek brytyjski. Natomiast w grudniu 2008 roku w Będzinie poprzez zabezpieczenie kilku maszyn oraz komponentów uniemożliwiono produkcję papierosów.

W dalszym ciągu Polska jest krajem tranzytowym w przemycie papierosów do krajów Europy Zachodniej, w szczególności do Wielkiej Brytanii, Francji, Włoch i Niemiec. W 2008 roku papierosy najczęściej były przemycane z Polski drogą lą- 
dową, ukrywane w naczepach pojazdów ciężarowych (w przewożonym towarze i w elementach konstrukcyjnych naczep). Natomiast do Polski papierosy przemycano drogą morską w kontenerach z Chin oraz drogą lądową z krajów byłego Związku Radzieckiego, ukrywane w naczepach pojazdów ciężarowych. W międzynarodowy przemyt papierosów były zaangażowane legalnie działające polskie przedsiębiorstwa transportowe i spedycyjne, kierowcy oraz nadawcy towarów. Coraz częściej jednak grupy przestępcze zakładają fikcyjne firmy, które w dokumentacji przewozowej są nadawcami ladunku.

W wymiarze statystycznym w 2008 roku CBŚ zabezpieczyło 76938007 sztuk papierosów, $10950 \mathrm{~kg}$ krajanki tytoniowej pochodzących z przemytu i zlikwidowanych nielegalnie działających fabryk oraz 164612 litrów spirytusu.

\section{Wyniki działań w zakresie rozpoznania i zwalczania terroru kryminal- nego oraz terroryzmu}

Na podstawie analizy sprawozdań z jednostek terenowych CBŚ oraz w wyniku monitorowania bazy KSIP od 1.01.2008 r. do 31.12.2008 r. odnotowano 39 przypadków eksplozji spowodowanych użyciem materiałów i urządzeń wybuchowych, w tym 20 przypadków noszących cechy aktów terroru kryminalnego. Powyższe eksplozje nastąpiły w związku z użyciem: urządzeń wybuchowych - 16 przypadków, granatów (4), rozbrajania niewybuchów i niewypałów (w celu odzyskania materiału wybuchowego) - 10, detonacji substancji chemicznej podczas produkcji materiału wybuchowego (9).

W 2008 roku ujawniono i rozbrojono podłożone pod różnymi obiektami 24 urządzenia wybuchowe, w tym 5 granatów oraz 19 urządzeń zawierających substancje wybuchowe. Ponadto ujawniono 16 atrap urządzeń wybuchowych.

W omawianym okresie 2008 roku odnotowano 579 fałszywych powiadomień o podłożeniu urządzeń wybuchowych w stosunku do 814 obiektów, zatrzymano 191 sprawców. Wykrywalność tej kategorii przestępstw kształtuje się na poziomie $32,99 \%$. Ponadto od 2008 roku odnotowano 50 powiadomień o odstąpieniu od zdetonowania ładunku wybuchowego w zamian za osiągnięcie korzyści majątkowej, zatrzymano 20 sprawców, wykrywalność zaś tych przestępstw osiągnęła poziom $40 \%$.

W 2008 roku w wyniku eksplozji materiałów wybuchowych śmierć poniosły 4 osoby (wybuchy spowodowane były w 3 przypadkach zamachami bombowymi, a w 1 przypadku manipulowaniem przy niewybuchach i niewypałach). Rannych zostało zaś 27 osób, w tym w wyniku: zamachów bombowych - 6 osób, próby detonacji niewypałów (5), wytwarzania i odzyskiwania materiału wybuchowego (6), konstruowania urządzeń wybuchowych (5) oraz nieszczęśliwego zbiegu okoliczności (5 osób, w tym jedno działanie samobójcze). 
Jeśli chodzi o efekty wykrywcze, to w wyniku przedsięwzięć policyjnych w 2008 roku zatrzymano 334 podejrzanych o działania przestępcze mające związek z materiałami i urządzeniami wybuchowymi ${ }^{15}$. Wobec 68 podejrzanych zastosowane zostało tymczasowe aresztowanie, wobec 22 podejrzanych - dozór policyjny lub poręczenie majątkowe. W odniesieniu do pozostałych 237 podejrzanych skierowano 123 wnioski do sądu grodzkiego, 114 wniosków do sądu rodzinnego i ds. nieletnich, zaś w 7 przypadkach odstąpiono od zastosowania środka zapobiegawczego i po przedstawieniu zarzutów zwolniono.

W wyniku dokonanych przeszukań odnaleziono i zabezpieczono 26 samodziałowych urządzeń wybuchowych oraz 2893,9 kg różnego rodzaju materiałów wybuchowych ${ }^{16}$. Najwięcej materiałów wybuchowych zabezpieczono na terenie województw podkarpackiego (1 548,5 kg), kujawsko-pomorskiego (499,1 kg), mazowieckiego (Warszawa - 274,7 kg) oraz lubelskiego $(237,7 \mathrm{~kg})$.

Należy podkreślić, że CBŚ w 2008 roku zabezpieczyło 401 sztuk broni palnej. Największe zabezpieczenia miały miejsce na terenie województwa śląskiego i podkarpackiego. Ponadto zabezpieczono 1035 sztuk różnego rodzaju niewybuchów, niewypałów i 47774 sztuki innej amunicji. Są to wyłącznie niewybuchy i amunicja zabezpieczone przez Policję, z których odzyskiwano lub planowano odzyskać materiał wybuchowy mający służyć do działań przestępczych. Najwięcej odzyskano w województwach: kujawsko-pomorskim - 481 sztuk oraz w lubelskim (335).

\section{Przewidywane kierunki rozwoju przestępczości zorganizowanej}

\section{Zorganizowana przestępczość kryminalna}

W tej kategorii przestępstw przewiduje się występowanie zdarzeń z użyciem broni palnej na tle porachunkowym o podział wpływów w grupach przestępczych, zwiększenie liczby kradzieży i handlu maszynami budowlanymi oraz rolniczymi znacznej wartości pochodzącymi z krajów Europy Zachodniej oraz ich redystrybucję i legalizację na podstawie fałszywych dokumentów w Polsce i w krajach Europy Wschodniej. Wiązać się z tym może poszerzenie wpływów polskich grup przestępczych na terenie Europy Zachodniej. Oznaczać to może częściową integrację z istniejącymi grupami zagranicznymi i zwiększenie udziału polskich organizacji przestępczych w takich krajach jak Wielka Brytania, Włochy, Hiszpania, Francja i Niemcy.

\footnotetext{
15 Ponadto ustalono i zatrzymano 191 sprawców fałszywych powiadomień o podłożeniu ładunków wybuchowych.

16 W tym 1,4 kg plastycznego materiału wybuchowego, 2667, $6 \mathrm{~kg}$ trotylu, $88,4 \mathrm{~kg}$ heksogenu, 58,4 kg górniczego materiału wybuchowego,53,8 kg prochu czarnego, $16,1 \mathrm{~kg}$ mieszanin pirotechnicznych oraz $8,3 \mathrm{~kg}$ innych substancji niebezpiecznych, 147 sztuk różnego rodzaju granatów, 20 sztuk petard wojskowych i innych środków pirotechnicznych oraz 8934 sztuki zapalników, detonatorów i spłonek.
} 
W konsekwencji może nastąpić zwiększenie rekrutacji członków polskich zorganizowanych grup przestępczych przez zagraniczne grupy celem uzyskania i umocowania przedstawicieli w krajach Europy Środkowej oraz poszerzenia wpływów.

$\mathrm{W}$ ostatnim czasie zauważono zjawisko związane z rozszerzeniem katalogu podmiotów zagrożonych ze strony członków zorganizowanych grup przestępczych. Przemoc, wraz z jej najostrzejszą formą, tj. zabójstwem na zlecenie, kierowana była dotychczas wobec niepokornych lub nieuczciwych członków własnej organizacji. Obecnie obserwuje się wzrost zagrożenia tego typu działalnością przestępczą, która wymierzona jest także w najbliższą rodzinę członków grup przestępczych oraz osoby zajmujące się ściganiem i zwalczaniem przestępczości zorganizowanej, w szczególności zaś policjantów i prokuratorów.

W dalszym ciągu utrzymywać się będzie wzrost zorganizowanego przemytu nielegalnych emigrantów pochodzących głównie z krajów azjatyckich, handlu ludźmi i czerpania korzyści z cudzego nierządu. $Z$ podobną tendencją możemy mieć do czynienia w odniesieniu do liczby falsyfikatów waluty euro, GPB i USD w obrocie krajowym, czemu towarzyszyć będzie rozszerzone działanie polskich i zagranicznych grup przestępczych zajmujących się przemytem falsyfikatów do krajów strefy euro oraz Wielkiej Brytanii.

\section{Zorganizowana przestępczość narkotykowa}

W tym zakresie należy przede wszystkim oczekiwać pojawienia się perturbacji w monitorowaniu substancji i prekursorów. Pojawią się w związku z dynamicznie zmieniającymi się sposobami produkcji narkotyków, pojawianiem się nowych narkotyków syntetycznych, zastępowaniem prekursorów znajdujących się pod ścisłą kontrolą innymi nowymi substancjami niepodlegającymi kontroli oraz utrudnieniami w monitorowaniu prekursorów i substancji chemicznych ze względu na dynamicznie zmieniające się sposoby produkcji.

Istnieje realne zagrożenie powstania nowych kanałów przemytu prekursora do produkcji amfetaminy (BMK) pochodzącego z terenu Rosji przez wschodnią granicę Polski (z terenu Litwy, Białorusi, Ukrainy) $)^{17}$. Prekursor ten bowiem jest produkowany legalnie w tamtejszych zakładach chemicznych. Może tez nastąpić wzrost nielegalnej produkcji prekursorów i narkotyków syntetycznych z niekontrolowanych substancji, przy wykorzystaniu nowych metod produkcji oraz sprzętu. Nadal utrzymywać się będzie zagrożenie ze strony substancji powodujących utratę świadomości, tzw. narkotyków gwałtu (m. in. GHB, ketamina, rohypnol). 
Elementem towarzyszącym emigracji zawodowej Polaków będzie produkcja i przemyt amfetaminy do krajów Europy Zachodniej. Drugim kierunkiem przemytu tego narkotyku będzie najprawdopodobniej Wschód, wykazujący rosnące zapotrzebowanie na narkotyki syntetyczne. Nastąpi tez zmiana produktu finalnego z proszku na tabletki. Kolejnym rosnącym zagrożeniem w wymiarze międzynarodowym będzie przemyt kokainy z Ameryki Południowej w tzw. transportach łamanych przez kraje Unii Europejskiej na rynek krajowy, jak i w tranzycie do innych krajów Europy.

$\mathrm{Z}$ innych prognozowanych zagrożeń $\mathrm{w}$ omawianym przedmiocie wskazać należałoby wskazać wzrost produkcji marihuany, w szczególności w wyniku organizowanych profesjonalnych plantacji konopi indyjskich, rosnące zagrożenie przemytem i handlem haszyszem, wzrost przemytu heroiny północną odnogą szlaku bałkańskiego i szlakiem jedwabnym zarówno na rynek krajowy, jak i w tranzycie do Europy oraz wzrost zagrożenia przemytem prekursorów oraz narkotyków w formie nowych niekontrolowanych substancji. Pojawiają się tu także zagrożenia związane z powstawaniem nielegalnych laboratoriów do odzyskiwania prekursorów oraz narkotyków.

\section{Zorganizowana przestępczość ekonomiczna}

Już wcześniejsza analiza prowadzonych przez CBŚ spraw pozwalała zaobserwować stale zwiększające się zagrożenie przestępstwami ekonomicznymi zarówno w sektorze finansowym, jak i gospodarczym. Zorganizowane grupy przestępcze w coraz większej mierze wykorzystują bowiem krajowy i międzynarodowy obrót handlowy do dokonywania przestępstw wyłudzeń podatku VAT oraz innych uszczupleń celno-podatkowych na szkodę Skarbu Państwa. Jednocześnie działalność taka służy do inwestowania i legalizacji zysków przestępczych oraz pomnażania dochodów służących popełnianiu dalszych przestępstw. Sprawcy przestępstw korzystają $\mathrm{z}$ coraz to nowych narzędzi, jakie oferuje rynek finansowy: factoring, akredytywa, kredyty rewolwingowe. Grupy przestępcze korzystają z ekspertów w zakresie rachunkowości, prawa podatkowego i finansowego celem jak najlepszego zakamuflowania przestępczej działalności oraz opracowywania i wdrażania nowych mechanizmów przestępczych ${ }^{18}$.

W najbliższej perspektywie spodziewać się można zintensyfikowania takich działań zorganizowanego świata przestępczego, jak:

- legalizowanie korzyści z działalności przestępczej poprzez inwestycje na rynku nieruchomości (również poza granicami kraju) oraz na rynku kapitałowym;

18 Zob. E. Pływaczewski, Kierunki zagrożeń przestępczością zorganizowaną w nowych krajach członkowskich na przykładzie Polski, (w:) Bezpieczni w Europie. Materiały konferencyjne pod redakcją Mieczysławy Zdanowicz, Warszawa 2007, s. 9 i nast. 
- nielegalna produkcja papierosów oraz nasilenie nielegalnego tranzytu papierosów przez Polskę do krajów Unii Europejskiej (pomimo wzrostu stawki akcyzy w Polsce), w których obciążenia akcyzowe są znacząco wyższe;

- wyłudzenia podatku VAT w międzynarodowym i krajowym obrocie towarami poprzez zastosowanie mechanizmu przestępczej karuzeli podatkowej;

- nielegalny obrót paliwem oraz jego komponentami przy wykorzystaniu różnic w opodatkowaniu produktów petrochemicznych czy zawieszonego poboru stawki akcyzy;

- wykorzystanie światowego kryzysu gospodarczego do manipulacji wartościami instrumentów finansowych (akcje, kontrakty terminowe, opcje walutowe);

- nielegalna działalność parabankowa oraz przestępczość na rynkach ubezpieczeniowych i funduszy inwestycyjnych;

- przetwarzanie i wprowadzenie do obrotu wyrobów spirytusowych;

- fikcyjne upadłości spółek;

- wyłudzenia na rynku nieruchomości, ze szczególnym uwzględnieniem nieruchomości należących do Skarbu Państwa, jak również wyłudzenia i nieprawidłowości w wykorzystywaniu funduszy unijnych;

- przestępczość na rynku budowlanym związanym z wysoko budżetowymi projektami inwestycyjnymi - EURO 2012 (wyłudzenia funduszy unijnych, nieprawidłowości w zamówieniach publicznych) oraz

- korupcja funkcjonariuszy publicznych.

\section{Terror kryminalny i terroryzm polityczny}

Przede wszystkim zwraca uwagę fakt, iż przestępcze wykorzystanie Intenetu będzie służyć grupom terrorystycznym i ekstremistycznym do propagowania swoich idei, werbowania członków i sympatyków oraz zwalczania przeciwników, anonimowego nakłaniania do popełniania przestępstwa, np. poprzez instruowanie, jak wytworzyć materiał wybuchowy lub urządzenie wybuchowe. Zwiększy się też zagrożenie terrorystyczne związane ze wzrostem aktywności radykalnych ugrupowań religijnych na terenie RP, wzrostem liczby cudzoziemców pochodzących z krajów tzw. „wysokiego ryzyka” przyjeżdżających do Polski w celach turystycznych, handlowych, starających się o polską wizę $\mathrm{w}$ celu podjęcia nauki na naszych uczelniach (głównie prywatnych) czy zawierających fikcyjne małżeństwa z Polkami.

Stałe rozpoznanie zagrożenia związanego z potencjalnym zamachami terrorystycznymi nie jest w Polsce niczym nowym. Podejmowane w tym zakresie czynności kierowane były głównie na rozpoznanie środowisk cudzoziemców z krajów tzw. „wysokiego ryzyka” oraz grup etnicznych i ekstremistycznych przebywających na terenie Polski. Zwalczanie terroryzmu nadal wymaga bezpiecznej sieci informacyjnej i finansowej, łącznie z Internetem, wykrywania i śledzenia działalności terrory- 
stycznej. W obecnej, cyfrowej erze niezwykle ważnym jest zwiększenie funkcji wywiadu oraz możliwości analizy (ilościowej i jakościowej) w różnych dziedzinach, wspólnie z cyfrowymi technologiami w celu śledzenia i ujmowania terrorystów. Specjalną uwagę należy przywiązać do broni chemicznej, biologicznej, nuklearnej, zarówno tradycyjnej, jak „domowej roboty” wykorzystywanej przez terrorystów, którą należy śledzić, wykrywać, identyfikować i neutralizować19.

Nowe zagrożenia związane mogą być z Mistrzostwami Europy w Piłce Nożnej „Euro 2012”20. Może też wzrosnąć aktywność organizacji neofaszystowskich oraz skrajnie lewicowych. Podobna tendencja dotyczy przestępczości z użyciem materiałów wybuchowych, uaktywnienia się konstruktorów urządzeń wybuchowych czy pozyskiwania materiałów wybuchowych na zamówienie osób trzecich.

Można też oczekiwać wzrostu - umiarkowanej jak dotąd - przestępczości cudzoziemców w Polsce poprzez uczestnictwo w grupach przestępczych i realizowanie zadań związanych z zastraszaniem, pobiciami, uprowadzeniami czy zabójstwami. Niezależnie od tego stwierdza się wzrost zainteresowania obszarem Polski ze strony zagranicznych grup przestępczych, w zakresie organizowania szlaków przemytniczych dotyczących broni, amunicji, materiałów wybuchowych i ludzi.

\section{Kierunki działań zmierzających do poprawy skuteczności zwalczania przestępczości zorganizowanej}

Analiza dotychczasowych działań CBŚ oraz ich efektów doprowadziła do wyeksponowania pewnych kierunków, których realizacja dawałaby gwarancje poprawy efektywności tej służby. Przede wszystkim głównym kierunkiem działań będzie monitorowanie liderów i członków zorganizowanych grup przestępczych pod kątem ich kondycji finansowej, w kontekście możliwości tworzenia nowych struktur przestępczych i poszerzania strefy wpływów. Równolegle przewiduje się tez monitorowanie liderów zorganizowanych grup przestępczych przebywających w zakładach karnych pod kątem odbudowywania przez nich starych lub tworzenia nowych struktur przestępczych po wyjściu na wolność, przy ścisłej współpracy z Centralnym Zarządem Służby Więziennej. Będą też prowadzone i koordynowane rozpoznania zagrożeń związanych z przygotowywaniem do Euro 2012 oraz przejęcia Prezydencji w Unii Europejskiej w 2011 roku.

\footnotetext{
19 Tamże, s. 15.

20 Problemy te były szeroko dyskutowane na „Europoltech 2009” - IV. Międzynarodowej Konferencji Policyjnej, zorganizowanej pod hasłem „Systemy bezpieczeństwa publicznego imprez masowych” (Warszawa, 22-24 kwietnia 2009 r.), w ramach II. Sesji plenarnej, zatytułowanej „Organizacja i zabezpieczenie wielkich imprez masowych - prezentacja doświadczeń wybranych krajów europejskich". Swoje doświadczenia w tym zakresie prezentowali przedstawiciele Niemiec, Holandii, Belgii, Austrii, Szwajcarii i Portugalii.
} 
Wypracowano tez i udoskonalono szereg przedsięwzięć mających na celu zwalczanie przestępczości narkotykowej, łącznie z działaniami na tzw. przedpolu. Należy tu w szczególności wyeksponować takie kierunki działań, jak:

- intensyfikacja współpracy w ramach powstałego zespołu roboczego Rady do Spraw Przeciwdziałania Narkomanii do spraw prekursorów narkotykowych oraz programu wczesnego ostrzegania o nowych narkotykach w zakresie monitorowania obrotu prekursorów oraz substancji chemicznych wykorzystywanych do nielegalnej produkcji narkotyków, jak również identyfikacji pojawiających się nowych narkotyków oraz metod ich produkcji i przemytu, kontynuowanie działań w ramach realizowanych projektów międzynarodowych dotyczących tego zagadnienia;

- współpraca w ramach realizowanych przez stronę polską międzynarodowych projektów angażujących państwa zagrożone przemytem prekursorów (Litwa, Ukraina, Białoruś, Rosja) lub rozważenie powołania nowych bilateralnych projektów, jak również współpraca w ramach projektów realizowanych przez Europol;

- intensyfikacja działań policyjnych w celu zwalczania nielegalnych laboratoriów produkujących narkotyki, ściślejsza współpraca w ramach realizowanych przez stronę polską międzynarodowych projektów angażujących państwa zagrożone produkcją narkotyków, wykorzystywanie baz analitycznych Eurpolu, organizowanie krajowych i zagranicznych szkoleń dla funkcjonariuszy służb publicznych zwalczających nielegalną produkcję narkotyków syntetycznych;

- włączenie się w realizowane przez instytucje rządowe i organizacje pozarządowe programy edukacyjno-profilaktyczne dotyczące substancji powodujących utratę świadomości, tzw. narkotyków gwałtu (m.in. GHB, ketamina, rohypnol) oraz nawiązanie ściślejszej współpracy z państwami producentami komponentów wymienionych substancji oraz ich pochodnych;

- zintensyfikowanie działań policyjnych w celu rozpoznania grup zajmujących się nielegalnymi uprawami konopi, współpraca międzynarodowa z policjami państw UE $w$ celu określenia wzajemnych powiązań grup przestępczych, skali, sposobu i organizacji prowadzenia nielegalnych upraw;

- zintensyfikowanie międzynarodowej współpracy z policjami państw UE oraz krajami trzecimi w celu określenia wzajemnych powiązań grup przestępczych, sposobu organizacji przemytu haszyszu szczególnie z terenu Azji i Afryki do Europy; współpraca w ramach powstałych inicjatyw międzynarodowych dotyczących tego zjawiska;

- zintensyfikowanie działań policyjnych w celu rozpoznania grup zajmujących się uzyskiwaniem niekontrolowanych substancji i ich pochodnych, identyfikacji tych substancji, sposobów oraz środków do odzyskiwania prekursorów i narkotyków z niekontrolowanych substancji; 
- zintensyfikowanie międzynarodowej współpracy z policjami państw Europy Wschodniej w celu określenia wzajemnych powiązań grup przestępczych, sposobu i organizacji przemytu heroiny z państw Azji przez wschodnią granicę Polski (głównie z Ukrainą); współpraca w ramach inicjatyw międzynarodowych dotyczących regionu Azji Centralnej oraz szlaków przemytu heroiny;

- ścisła współpraca ze Służbą Celną i Strażą Graniczną w celu ograniczenia przemytu narkotyków, wyrobów tytoniowych i nielegalnej produkcji papierosów;

- współpraca w ramach realizowanych przez stronę polską międzynarodowych projektów angażujących państwa zagrożone przemytem produktów tytoniowych (Litwa, Ukraina, Białoruś, Rosja, Niemcy, Belgia, Holandia, Wielka Brytania) oraz realizowanie nowych, bilateralnych projektów;

- zintensyfikowanie międzynarodowej współpracy z policjami państw UE oraz Ameryki Południowej w celu określenia wzajemnych powiązań grup przestępczych, sposobu organizacji przemytu kokainy z Ameryki Południowej do Europy;

- kontynuowanie rozpoznania operacyjnego wybranych środowisk cudzoziemców pod kątem zagrożenia terrorystycznego i ekstremistycznego oraz konstruktorów urządzeń wybuchowych;

- monitorowanie Intenetu pod kątem muzułmańskich treści radykalnych mogących mieć potencjalny wpływ na zagrożenia o charakterze terrorystycznym w RP;

- prowadzenie rozpoznania zagrożeń związanych z użyciem materiałów wybuchowych, a szczególnie konstruktorów urządzeń wybuchowych oraz tzw. pozyskiwaczy materiałów wybuchowych, którzy na zamówienie osób trzecich nielegalnie odzyskują materiały wybuchowe z wojskowych lub górniczych urządzeń wybuchowych, w tym z niewybuchów;

- kontynuacja udziału w pracach zespołu przy MSWiA, którego zadaniem będzie wypracowanie projektu Ustawy Antyterrorystycznej, współpraca z Centrum Antyterrorystycznym ABW w zakresie wymiany informacji o zagrożeniach terrorystycznych w Polsce;

- udział w pracach Stałego Komitetu Ekspertów przy Komisji Europejskiej ds. prekursorów materiałów wybuchowych;

- udział w pracach nad wdrażaniem na terenie Polski elektronicznego systemu śledzenia materiałów wybuchowych - program „SCEPYLT”;

- koordynacja zagadnień dotyczących nieproliferacji broni masowego rażenia - koordynacja przedsięwzięć Policji (CBRN);

- wypracowanie formalnoprawnych unormowań ułatwiających Policji dostęp do informacji bankowej i ubezpieczeniowej oraz dostęp Policji do tajemnicy skarbowej i wypracowanie odpowiednich procedur w tym zakresie; 
- udoskonalanie wspólnie z krajowym biurem ds. odzyskiwania mienia systemu odzyskiwania mienia, wdrożenie systemu ESOM umożliwiającego skuteczniejsze ujawnianie składników majątkowych, sprawniejsza współpraca ze służbami skarbowymi w zakresie pozbawiania sprawców majątku, szczególnie w ramach współpracy międzynarodowej, postępowania podatkowego oraz egzekucji zabezpieczonego mienia.

Wspomnieć też trzeba o nowych rozwiązania mających na celu usprawnienie tak ważnej dla funkcjonowania CBŚ współpracy międzynarodowej ${ }^{21}$. Przede wszystkim w Wydziale Wywiadu Kryminalnego CBŚ została powołana Sekcja Współpracy Międzynarodowej22, która kontynuuje realizację zadań dotyczących współpracy operacyjnej i pozaoperacyjnej CBŚ z partnerami zagranicznymi. Uprzednio zadania te były wykonywane przez Zespół ds. Współpracy Międzynarodowej (powołany 26 września 2007 roku). Utworzenie Sekcji wiąże się ściśle z rozbudową pionu współpracy międzynarodowej w CBŚ, wynikającą z odnotowanej wzrastającej liczby zleceń dotyczących problematyki pozaoperacyjnej kierowanych do Biura, np. w sprawach wypracowania stanowisk m. in. na temat koncepcji organizacji współpracy, ocen dotyczących raportów i dokumentów unijnych, opinii aktów prawnych (głównie międzynarodowych umów międzyrządowych w sprawach współpracy w zwalczaniu przestępczości).

Wpływ na powołanie Sekcji Współpracy Międzynarodowej w CBŚ miała także potrzeba zabezpieczenia zdolności Biura do adekwatnego reagowania na zadania wynikające ze zbliżającego się objęcia w roku 2011 Prezydencji w Unii Europejskiej przez Rzeczpospolitą Polską, w szczególności w fazie przygotowań. Na podstawie analiz napływających danych Sekcja opracowuje m. in. informacje dotyczące sytuacji w takich obszarach tematycznych, jak: międzynarodowa wymiana informacji z uwzględnieniem rodzaju przestępstw i regionu świata; inicjatywy międzynarodowe z udziałem pracowników i funkcjonariuszy Biura; spotkania międzynarodowe; sprawy, operacje międzynarodowe; szkolenia międzynarodowe.

Odstąpiono też od scentralizowanego modelu międzynarodowej wymiany informacji kryminalnych, zakładającego przesyłanie zapytań przez Wydział Wywiadu Kryminalnego CBŚ od/do partnerów zagranicznych, umożliwiając prowadzenie bezpośredniej wymiany komórkom terenowym Biura. Rozwiązanie to ma charakter praktyczny i pozwala zdynamizować przepływ zleceń. Jednocześnie poleceniem Dyrektora CBŚ zobligowano komórki Biura do wprowadzania informacji uzyskanych w obrocie międzynarodowym do systemów informacyjnych Policji. (w:) W kręgu teorii i praktyki prawa karnego. Księga poświęcona pamięci Andrzeja Wąska, Lublin 2005, s. 671 i nast. 


\section{Podsumowanie}

Centralne Biuro Śledcze działa już ponad 8 lat jako wyspecjalizowana komórka organizacyjna Komendy Głównej Policji. O skuteczności działań tej formacji świadczyć mogą dane statystyczne zgromadzone za lata 2000-2008. W okresie tym przeszło 34.000 podejrzanym przedstawiono ok. 99 tys. zarzutów. Około 11 tys. osób otrzymało zarzuty z art. 258 par 1 i 2 kk. o uczestnictwo i popełnianie przestępstw w ramach zorganizowanej grupy przestępczej, w tym ok. 930 osobom przedstawiono zarzuty przewodzenia grupie przestępczej. W prowadzonych sprawach zabezpieczono mienie na kwotę przeszło 1,7 mld złotych, odzyskano mienie na kwotę ponad 292 mln złotych. W ramach zwalczania przestępczości narkotykowej zlikwidowano 129 laboratoriów narkotyków syntetycznych, zabezpieczono ponad 1,5 tony amfetaminy, przeszło $676 \mathrm{~kg}$ heroiny, ponad tonę marihuany oraz kokainy. Likwidacji uległy ,grupa pruszkowska”, ,,wołomińska”, których zasięg obejmował nie tylko terytorium kraju, ale również powiązania międzynarodowe, grupy lokalne, jak ,wyszkowska”, „nowodworska”, grupy charakteryzujące się dużą bezwzględnością działań kierowane przez „Oczkę”, „Krakowiaka” czy „Caringtona”. Zlikwidowano dziesiątki laboratoriów narkotykowych, miejsc nielegalnej produkcji wyrobów tytoniowych czy alkoholowych. Skutecznie rozpoznawano szlaki przemytu ludzi, wyrobów akcyzowych, komponentów do produkcji narkotyków syntetycznych, paliw.

Istotnym elementem realizowanych przedsięwzięć pozostawało rozpoznanie zaplecza finansowego grup zorganizowanych. Systematycznie podejmowano działania w stosunku do zorganizowanych grup specjalizujących się w popełnianiu przestępstw gospodarczych. Niejednokrotnie w pracy służby zwalczającej zorganizowaną przestępczość ujawniano nowe rodzaje przestępstw godzących bezpośrednio w obrót gospodarczy i stabilność finansową.

Wydaje się, iż możliwości i ogromny potencjał Centralnego Biura Śledczego nie są do końca efektywnie wykorzystywane. Na pewno nie wystarczy, że funkcjonariusze CBŚ podnoszą swoje kwalifikacje zawodowe, aby móc sprostać stawianym przed nimi zadaniom. W moim przekonaniu należałoby pilnie zastanowić się na strukturalnym usytuowaniem tej formacji, która tkwiąc w sztywnych ramach Komendy Głównej Policji, podlega takim samym rygorom i ograniczeniom jak inne Biura, nawet z kilkudziesięciokrotnie mniejszym stanem osobowym. Na pewno nie wpływa to na szybkość i efektywność działań.

Naprzeciw tego rodzaju oczekiwaniom wychodzą zainicjowane w lutym $2008 \mathrm{r}$. przez kierownictwo Ministerstwa Spraw Wewnętrznych i Administracji prace nad zmianą przepisów kilku ustaw regulujących funkcjonowanie służb nadzorowanych przez ministra właściwego do spraw wewnętrznych. Efektem tych prac jest projekt ustawy o zmianie ustawy o Policji i niektórych innych ustaw w wersji z 26 sierpnia 2009 r., który został skierowany do uzgodnień międzyresortowych. 
$\mathrm{W}$ interesującym nas zakresie projekt ten przewiduje wprowadzenie do struktur Policji nowego rodzaju jednostek - centralnych jednostek organizacyjnych Policji, które w założeniu mają realizować niektóre zadania na poziomie ogólnokrajowym na określonych polach aktywności Policji, zwłaszcza w sferze wykonawczej. Zadania te obecnie są realizowane przez niektóre komórki organizacyjne Komendy Głównej Policji, jednakże dotychczasowe ich usytuowanie z punktu widzenia sprawności kierowania oraz zarządzania nimi rodzi wiele problemów i niepotrzebnie angażuje bezpośrednio komendanta głównego Policji. Charakterystycznym tego przykładem może być właśnie Centralne Biuro Śledcze, które według proponowanej formuły nowelizacyjnej miałoby zapewnione otwarte pole do zwiększenia efektywności swoich działañ ${ }^{23}$. 


\section{SUMmarY}

The article starts with general remarks in which the author focuses on the difficulties in drawing a dividing line between traditional crime and organized crime. He highlights the fact that some tendencies, which are typical of traditional crime, generally are not present in organized crime, contrary to numerous stereotypical beliefs regarding the latter. Next, the author discussed the dynamics and the structure of organized crime, on the basis of reports and analyses of the Central Bureau of Investigation (CBŚ) and the results of preparatory proceedings and criminal reconnaissance aimed at combating criminal terror and terrorism. In the following part of the article, the author presents possible future developments in organized crime in such areas as criminal offences, drug offences, economical offences, as well as criminal and political terror. In the fourth part of the article, based on an analysis of the activities of the CBŚ and their outcomes, the author proposes certain measures that should be implemented to improve the effectiveness and efficiency of the Bureau in fighting organized crime. Also, the author presents new solutions aimed at improving international cooperation, which is a very important element of the Bureau's operations. In the conclusions, the author states, among others, that the great potential and capacities of the Central Bureau of Investigations are not used the most effectively and that a new position of the Bureau in the law-enforcement structures is required. This is because the Bureau is a part of the rigid structure of the Chief Police Headquarters, which often imposes unnecessary restrictions and limitations on the speed and efficiency of the Bureau's operations. 